\title{
Tecnomatix: A Born Global Company
}

Tamar Almor, (Email: talmor@colman.ac.il), College of Management, Israel

\section{INTRODUCTION}

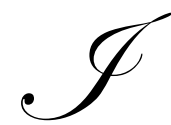

$\mathrm{n}$ the beginning of 2004, Tecnomatix Technologies Ltd. (NASDAQ: TCNO), the driving force in Manufacturing Process Management (MPM), announced a global agreement with Ford, a major automotive manufacturer. The agreement to implement Tecnomatix MPM solutions throughout the customer's manufacturing operations worldwide represented an expansion of an existing relationship with this manufacturer and was expected to generate total revenues in excess of US\$50 million over the next four years.

At the beginning of 2004 Tecnomatix, an Israel-based high-tech company, held a staggering $70 \%$ market share (over 2,000 clients) in the MPM market together with its strategic partner, EDS. Although the company reported a net loss in 2003, it had sufficient cash reserves that would allow it to continue operations without needing external funding for the down period.

\section{COMPANY HISTORY}

Tecnomatix, based in Herzliya, Israel, was founded as a division of Oshap in the early 1980's. In 1983 Tecnomatix got on to a new start, breaking away from its mother company, Oshap. The company's first product was a software solution for digitally planning and simulating a production line (CAPE). In 1993 the company made an initial public offering on the NASDAQ stock exchange, to raise money that would allow it to expand its marketing network, allowing the company to grow. A second public offering took place in 1996. The company raised additional money by issuing convertible bonds in 1997.

During the end of the 1990's the company became a pioneer in the Manufacturing Process Management (MPM) field, through in-house R\&D and a series of mergers, acquisitions, and strategic alliances. In the year 2000 the company unveiled its first complete MPM solution, utilizing the Internet as a means to transfer production line information between product designers and manufacturers in a decentralized environment. The same year marked the opening of the company's international customer service center, employing 150 application and service engineers, serving customers from a myriad of countries worldwide.

The main difference between the company's original CAPE products and the new MPM products was that CAPE products enhanced individual productivity at the engineer level while MPM products provided, for the first time, a holistic enterprise solution. This shift in focus required Tecnomatix to aim its marketing efforts at different clients than before. Referring to this change, Tecnomatix chairman, Harel Beit-On, said "we consider ourselves market creators and thought leaders, always planning ahead of the curve."

It was only in the first three years of the third millennium (2000-2002) that the company managed to secure strategic alliances with some of the world's leading software and electronics giants - SAP, EDS PLM Solutions, Teradyne, and Fuji. These alliances were expected to bring added value to their mutual customers, while elevating Tecnomatix's status to be recognized as "playing with the big boys".

Copyright Dr. Tamar Almor, who prepared this case study with the help of Udi Lederer (MBA) for educational purposes rather than to illustrate either effective or ineffective handling. We would like to thank Arik Korman for his assistance in preparing this case study. The case study was funded by the Research Unit of the School of Business Administration, The College of Management, Israel. 


\section{THE MARKET}

An early use of computers in the manufacturing industry was CAD/CAM (Computer Aided Design / Computer Aided Manufacturing) that allowed product designers to surrender their blue-prints, pencils, and rulers, in favor of sophisticated computer programs that allowed them to design, simulate, and prepare their products for production, in a fracture of the time it used to take them.

Later on, manufacturing plants searched for a solution that would allow digital planning of their production lines, much like the digital planning of their actual products. In lack of such an off-the-shelf product, solutions were found in forms of in-house software development and made-to-order products. By the late 1990's these solutions were becoming outdated, incompatible with current production techniques and tools, and in desperate need of upgrading and sophisticating.

Tecnomatix caught on to this vacuum and set out to make the first move and become a pioneer in the MPM market. The MPM market offers solutions designed to handle products throughout their entire product lifecycle starting from their initial planning ("what"), through their production design, production simulation, management and execution of their actual manufacturing ("how"), up to the relevant raw materials purchasing and enterprise inventory management ("when and where").

The key advantages that MPM products offer are:

- $\quad$ Shorter time-to-market for planned products;

- $\quad$ Increased throughput and flexibility for manufacturing plants;

- $\quad$ Minimizing design- and production-related costs;

The MPM market has been characterized in recent years by smaller companies partnering and consolidating to better meet the market demands. The global MPM market is expected to grow at an average annual rate of 33.2\% during the ten years between 2001 and 2011, growing from an annual $\$ 157.7 \mathrm{M}$ market in the year 2001 to an annual $\$ 2,764.1 \mathrm{M}$ market (almost $\$ 3$ billion) in the year $2011^{1}$. However, this growth will not be the result of a direct continuation of current marketing strategies, as Tecnomatix CEO, Harel Beit-On puts it "as client needs are changing and becoming more specific, we are already seeing a shift from mass marketing to mass customization."

It is important to understand that an MPM solution consists of an IT part (usually software) and a professional services part (usually software customization, deployment efforts, training, etc.). MPM providers are constantly trying to unbalance these two parts of their solution offering in favor of the IT part, due to its much higher profit margin. Professional services typically have a break-even financial bottom line, at best.

\section{CLIENTS}

The MPM market caters to clients from three major industries:

- $\quad$ The auto industry, comprising 37\% of the MPM market's clientele in the year 2001. These clients are well known names such as Renault, GM, DaimlerChrysler, Audi, Volkswagen, Kia, Nissan, Mazda, Fiat, Ford, BMW, and others.

- $\quad$ The aerospace industry, comprising $21 \%$ of the MPM market's clientele in the year 2001. These clients include companies such as EADS Airbus, Pratt \& Whitney, British Aerospace, Israeli Aircraft Industries, and others.

- $\quad$ The electronics industry, comprising $14 \%$ of the MPM market's clientele in the year 2001. These clients include electronics giants such as Philips, Siemens, Canon, Fuji, and others.

The remaining $28 \%$ of the MPM market's clientele includes companies from other industries. Their take in the MPM market is expected to decrease to $13.6 \%$ by the year 2011, while the auto industry's share of business will

\footnotetext{
${ }^{1}$ Frost \& Sullivan Presentation, World MPM Markets, www.frost.com, Industry Research, 2002.
} 
slightly increase to $38.8 \%$ (since this market is pretty well saturated by now). The aerospace industry share is expected to diminish to $11.0 \%$, due to the limited nature of this industry's business (there is only a certain number of aircrafts and space shuttles the world needs), and the electronics industry's share will rise to an impressive $36.5 \%$ explained by the increase in electronics production of small appliances such as cellular phones, who's production techniques are considered far inferior to those of the auto industry's, to name one example.

Despite the breakdown of clients into several distinct sectors, most clients that buy MPM solutions are facing similar challenges: (1) time to market - the competitive landscape of most industry sectors demands that companies wishing to stay in the game bring their new products to the market faster than ever before. This requires creative IT solutions to make sure no time is wasted on information transferring, duplication, or loss; (2) a growing number of products - many companies refuse to take the risk of putting all their eggs in the same basket, so to speak, resulting in an ever-growing product range. Managing these product lines requires effective knowledge management techniques to make sure that the company's overhead costs don't grow out of control; and (3) trend towards outsourcing non- corecompetency operations. This trend helps the organization keep its fixed costs to the necessary minimum, reducing the risk of cash flow difficulties in times of diminished sales.

\section{COMPETITION}

The MPM solution providers' target markets may be divided into two groups:

- The electronics market: Tecnomatix is the leading competitor in this market, followed by (in descending order of market share) Delmia (a subsidiary of Dassault Systèmes, a company in the CAD/CAM business) and EDS. The partnership forged between Tecnomatix and EDS in the year 2002 make them a de facto MPM industry monopoly, with a whopping $70 \%$ market share, contested only by Delmia.

- The auto, aerospace, and other industries: here too Tecnomatix is the leading MPM solution provider, followed by (in descending order of market share) Aegis, Valor, and GenRad.

\section{Delmia}

Delmia $^{2}$, founded in 1985, is headquartered in Delaware, USA. Delmia is a wholly owned subsidiary of Dassault Systèmes, a giant French company. Its financial reports are not separated from those of the mother company. Delmia designs and markets a comprehensive suite of digital manufacturing software. Its mission is to provide the manufacturing community with e-solutions to plan, create, monitor and control manufacturing systems geared towards built-to-order and lean production, from single-device activity to extended-enterprise production flow. Coverage supplied by the company's software solutions extends from the conceptual phase of product and process design, through simulation and monitoring of manufacturing processes, to shop floor operations such as capacity planning, implementation and monitoring. Application suites are available for process planning, cost estimation, factory layout, ergonomics, robotics, machining, inspection, factory simulation, and execution.

\section{Aegis}

Aegis $^{3}$ started out in 1995 when a manufacturing engineer, working in a PCB (Printed Circuit Board) design and assembly company, needed to program production machines and document operator visual aids and instructions more quickly. He wanted a better tool than those available at the time to convert CAD into these outputs. To create the tool, he approached another manufacturing engineer who specialized in Windows software for automating large manufacturing process equipment. They combined skills and efforts to create a basic software tool to solve the problem. This software tool was Aegis's first product. By the end of 2002, 26 machine manufacturers were aligned with Aegis's products and the customer base exceeded 450. Public financial data on the company is not currently available.

\footnotetext{
${ }^{2}$ For more information on Delmia go to www.delmia.com

${ }^{3}$ For more information on Aegis go to www.aiscorp.com
} 
Valor

Valor $^{4}$ is an Israel based company founded in 1992. It provides high-level data exchange tools for the electronics industry, ensuring the rapid data transfer of optimized data from design concept down to the factory floor. Valor is publicly listed on the Frankfurt Stock Exchange (Prime Standard: VCR) and has regional sales and customer service offices throughout North America, Europe, and the Far East. R\&D facilities are located in Israel, Europe, and North America. The company’s 2002 revenues just topped \$23 million.

\section{GenRad}

GenRad $^{5}$ was acquired by Teradyne (today a Tecnomatix partner) in October 1999. In a May 2002 press release the company announced the renaming of GenRad to Teradyne Diagnostic Solutions. "Teradyne is a strong technology-oriented company with a history of innovation, quality and growth. We are pleased to be associated with the Teradyne name and expect to go from strength to strength." said Peter Miles, General Manager of Teradyne Diagnostic Solutions. Teradyne Diagnostic Solutions provides a complete modular turnkey system for the automotive assembly line, bringing together customization, technology and quality. Teradyne's Vehicle Configuration and Test Solutions (VCATS) configure and test individual components using web-based data preparation and real time reporting throughout the vehicle manufacturing process. These components enable the manufacturer to obtain higher functionality, low cost of ownership, reduced cycle times and improved 'Right First Time' performance.

\section{THE COMPANY}

Harel Beit-On describes the current company philosophy as "trying to get out of the comfort of the MPM market niche and expand the company's offerings to complimentary products." An example of this can be found in a company press release summarizing the year 2003 financial results. In this press release Beit-On stated:

(In 2003) we executed our strategy in order to broaden the footprint of MPM into other high-potential areas of manufacturing when we acquired the assets and liabilities of USDATA, including its highly regarded FactoryLink and Xfactory products. This acquisition will enable us to expand our business by addressing the high-growth production management domain, as well as entering into new industries.

In the year 2000 the company felt very pressed to release its new MPM product suite, after which it reduced its R\&D staff by cutting back on personnel expenses and starting a reorganization process aimed at making the company leaner and more efficient. As of early 2004, Tecnomatix employed nearly 700 employees in 21 countries, major centers being the Israel headquarters and R\&D center, where 160 employees worked, the US division, which included people employed formerly by Unicam, a company that was acquired by Tecnomatix in 1999, and the China office where 30 local employees worked. Overall, the company employed 240 employees in field operations (sales \& support), 200 in R\&D, 140 in professional services (the company calls these employees "consultants" who are located primarily in Germany, the US, and Japan), 50 in the support hotline call center, and 25 general and administrative personnel.

In the year 2000 the company reduced its marketing and sales (M\&S) expenses by cutting back personnel, but to a smaller degree compared to the R\&D department cutbacks, because the sales \& marketing employees are the ones that manage the pilot projects at client sites. Company statistics show that approximately $50 \%$ of these pilot projects eventually transform into sales. The salesperson who manages a pilot project is typically a senior salesperson with software or other technical background that tries to perform what the company calls the "value discovery process". Simply put, this is the task of finding out exactly what the client needs and how much of it can Tecnomatix provide. A typical pilot projects starts out as a $\$ 100,000$ project, and if successful, quickly builds up into a $\$ 1,000,000$ project, then a $\$ 10,000,000$ project, and so on. In early 2004 , Tecnomatix had some 300 active pilot projects.

\footnotetext{
${ }^{4}$ For more information on Valor go to www.valor.com

${ }^{5}$ For more information on GenRad (now part of Teradyne) go to www.teradyne.com
} 
One example of a well-matured client account can be found in a December 2003 press release announcing the company's largest-ever four-year global agreement with an undisclosed client, with expected revenues of over $\$ 50,000,000$. Referring to this deal, Beit-On said

"Tecnomatix has been working with this customer on several implementations over the past few years and we have been able to deliver significant value during that time. Our eMPower solutions have reinforced their global virtual manufacturing programs and key enterprise strategies, including flexible manufacturing, digital process validation, capital asset reuse, and the alignment of products and process development. We continue to gain momentum with the world's leading manufacturers as they recognize the invaluable manufacturing efficiencies and cost benefits of implementing our eMPower solutions throughout the enterprise. Tecnomatix has always been a pioneer in the virtual manufacturing and process planning domains and this agreement solidifies our position as the leader in the multibillion dollar MPM market."

\section{ORGANIZATIONAL STRUCTURE}

In the year 2000 Tecnomatix transformed its functional organizational structure into a divisional organizational structure (two divisions) based on client industries - one division caters to clients from the electronics industry (Tecnomatix Unicam, which brings in approximately $20 \%$ of company sales) and the second division deals with clients mainly from the auto and aerospace industries (which accounts for approximately $80 \%$ of company sales). This organizational structure is a result of the company's recognition of the drastically versatile workflows its clients incorporate, that don't allow the same product to be used across different industries.

Tecnomatix Unicam is a fully owned subsidiary operating in the US, employing local R\&D personnel. Unicam Tecnomatix is the result of an acquisition by the company in 1999 of an American start-up by the name of Unicam. Originally, Unicam (USA) developed software applications for printed circuit boards' assembly in the electronics industry.

The second division is run from Israel employing Israeli R\&D personnel. The company's management and administrative headquarters (finance, business development, and sales management) are located in Israel.

Tecnomatix operates sales and support offices in over 20 countries worldwide and maintains an additional 12 distributors in countries or regions where there is no financial justification to operate a fully owned office at this stage. A minority of the offices also perform R\&D tasks, mainly for localization purposes. A list of countries in which the company's main offices and distributors are located can be found in Appendis 1.

The company is gradually moving towards a matrix organizational structure, its two dimensions being (1) business units (i.e., auto, aerospace, and electronics) and (2) geographic territories (e.g., the US, Germany, Japan).

In a February 11, 2004 press release the company announced that its 8-year CEO Harel Beit-On will remain active only as chairman of the board and leave the CEO position in favor of Jaron Lotan, who will continue to serve as president of Tecnomatix and previously served as chief operating officer.

\section{MERGERS, ACQUISITIONS, \& STRATEGIC ALLIANCES}

The MPM market is characterized by customers that expect an end-to-end solution to their needs. They don't want to be forced to work with countless software vendors, integrators, and software maintenance personnel. They want to minimize the number of vendors they work with, while minimizing costs and maximizing effectiveness and efficiency.

Understanding that leading partners are crucial to its success, Tecnomatix participated in several mergers, acquisitions, and strategic alliances, over the years. A short summary of these M\&As and strategic alliances can be found in Appendix 2. 
Beit-On explains that a typical M\&A at Tecnomatix goes through three distinct, serial stages: (1) administrative cooperation - this is the first stage after the merger or acquisition when the companies are getting to know each other and cooperate at a basic level between them; (2) cross-selling - this is the second stage that occurs when the companies know each others products well enough to start mutual marketing; and (3) product integration only after some time has past from the merger or acquisition can the two companies feel confident enough about their clients' needs to try and partially of fully integrate their products to better suit them.

Two of Tecnomatix's partners, EDS and SAP, stand out:

- $\quad$ EDS $^{6}$ is one of Tecnomatix's most important partners. Previously a competitor, EDS was founded in 1962 and is headquartered in Texas, USA. EDS is one of the world's largest IT (Information Technologies) outsourcing vendors. With 138,000 employees, over 35,000 business and government clients worldwide, and $\$ 21.5$ billion in revenues in 2002, EDS is in a position to be a crucial partner to Tecnomatix's success. Tecnomatix and EDS are working jointly at efforts to homogenize client information, allowing for streamline operations between business units and data formats. The two companies hope to achieve this goal by cooperation in both their R\&D and marketing departments. 2003 marked the first revenues of this joint effort, which both companies expect to become even more lucrative in the future.

- $\quad \mathrm{SAP}^{7}$, founded in the 1970's in Germany, is the world's third-largest independent software company. SAP provides solutions for ERP (Enterprise Resource Planning), CRM (Customer Relationship Management), SCM (Supply Chain Management), and other related fields. With over 19,300 clients, 10 million users, 60,100 installations, 29,000 employees worldwide, and nearly $€ 7.5$ billion in revenues in 2002, SAP is definitely a partner Tecnomatix could use on its side.

\section{FINANCIALS}

The company's last annual financial reports are of 2003. Table 1 presents key financial data for the years 1999-2003. Full balance sheets and P\&L can be found in Appendix 3. Financial indexes for the software industry can be found in Appendix 4.

The figures show a trend towards minimizing losses and shifting into expected profit in 2004. This trend took place during a period of deep worldwide economic recession that hit the software industry especially hard. While other companies were deepening their losses and other filed for chapter 11, Tecnomatix managed to tighten its belt, become more efficient, and diminish losses dramatically (between 2000 and 2002). A significant part of the cutting back was in personnel expenses, but this was done in a way that would not harm the company's future revenues, only future product developments. In the years 2001-2002 the company focused on expediting client site integrations rather than on developing future products.

Beit-On explained that $40 \%$ of sales in 2003 were of products developed in the last three years and that Tecnomatix was trying to reach an ambitious annual growth rate of $25 \%-30 \%$, to meet the $\$ 100,000,000$ sales mark within a few years, and then move up to the $\$ 500,000,000$ mark. These goals may not seem too far fetched when considering that Tecnomatix was rated number 195 out of the world's top 500 software vendors in Software Magazine's 2003 "Software 500"8 ranking, moving up 15 spots from its 2002 ranking. The "Software 500" list includes both private and public companies, with rankings based on total worldwide software, licenses, and service revenue.

Despite the company's various successes and its growth, Harel Beit-On wondered if the company could remain independent over time. The industry was becoming dominated by large players and the larger Tecnomatix would grow, the more attention it would draw from those competitors. In addition, it seemed that the industry would mature in a number of years. Moreover, the basis of the company in Israel put a lot of strain on all its senior managers,

\footnotetext{
${ }^{6}$ For more information on EDS go to www.eds.com

${ }^{7}$ For more information on SAP go to www.sap.com

${ }^{8}$ The "Software 500" list appeared in Software Magazine's December 2003 issue, and online at www.softwaremag.com
} 
who had to travel constantly to keep in touch with all the company's employees, clients and future prospects who were located outside Israel.

As a result, Beit-On wondered how long it would take before one of the companies in the industry would commence talks regarding the acquisition of Tecnomatix and, more importantly, how the Board would vote on such an offer.

Table 1 - Key Financial Data 1999-2002

\begin{tabular}{|c|c|c|c|c|c|c|c|c|c|c|}
\hline & \multicolumn{2}{|c|}{$\mathbf{1 9 9 9}$} & \multicolumn{2}{c|}{$\mathbf{2 0 0 0}$} & \multicolumn{2}{c|}{$\mathbf{2 0 0 1}$} & \multicolumn{2}{c|}{$\mathbf{2 0 0 2}$} & \multicolumn{2}{c|}{$\mathbf{2 0 0 3}$} \\
\cline { 2 - 11 } & $\mathbf{\$ K}$ & $\mathbf{\%}$ & $\mathbf{\$ K}$ & $\mathbf{\%}$ & $\mathbf{\$ K}$ & $\mathbf{\%}$ & $\mathbf{\$ K}$ & $\mathbf{\%}$ & $\mathbf{\$ K}$ & $\mathbf{\%}$ \\
\hline Sales & 88,018 & $100 \%$ & 89,018 & $100 \%$ & 86,900 & $100 \%$ & 82,005 & $100 \%$ & 86,257 & $100 \%$ \\
\hline R\&D & 16,451 & $19 \%$ & 20,748 & $23 \%$ & 19,216 & $22 \%$ & 14,812 & $18 \%$ & 14,960 & $17 \%$ \\
\hline $\begin{array}{c}\text { Marketing } \\
\& \text { Sales }\end{array}$ & 39,333 & $45 \%$ & 50,737 & $57 \%$ & 44,624 & $51 \%$ & 36,887 & $45 \%$ & 42,491 & $49 \%$ \\
\hline $\begin{array}{c}\text { Operating } \\
\text { Profit } \\
\text { (Loss) }\end{array}$ & $(1,330)$ & $\begin{array}{c}\text { Nega- } \\
\text { tive }\end{array}$ & $(20,673)$ & $\begin{array}{c}\text { Nega- } \\
\text { tive }\end{array}$ & $(14,515)$ & $\begin{array}{c}\text { Nega- } \\
\text { tive }\end{array}$ & $(1,748)$ & $\begin{array}{c}\text { Nega- } \\
\text { tive }\end{array}$ & $\begin{array}{c}(10,704) \\
\text { Nega- } \\
\text { those }\end{array}$ \\
\hline $\begin{array}{c}\text { Net Profit } \\
\text { Loss }\end{array}$ & 1,354 & $2 \%$ & $(19,959)$ & $\begin{array}{c}\text { Nega- } \\
\text { tive }\end{array}$ & $(13,910)$ & $\begin{array}{c}\text { Nega- } \\
\text { tive }\end{array}$ & $(2,830)$ & $\begin{array}{c}\text { Nega- } \\
\text { tive }\end{array}$ & $\begin{array}{c}(10,340) \\
\text { Nega- } \\
\text { tive }\end{array}$ \\
\hline
\end{tabular}

\section{APPENDIX 1 - INTERNATIONAL OFFICES AND DISTRIBUTORS}

The company's main offices are located in the following countries (some countries host several offices):

- $\quad$ Europe: Israel (headquarters), Belgium, France, Germany, Italy, Holland, Spain, Sweden, and Great Britain.

- $\quad$ America: US and Canada.

- $\quad$ Asia: China, Japan, Korea, Malaysia, Singapore, and Taiwan.

Local distributors are found in these countries:

- $\quad$ Europe: Holland, Spain, and Turkey.

- $\quad$ America: Brazil.

- $\quad$ Asia: Australia, Hong Kong, Korea, India, Singapore, and Taiwan.

\section{APPENDIX 2 - MERGERS, ACQUISITIONS, \& STRATEGIC ALLIANCES}

1997 Acquisition of Aesop (Germany) - products for optimally planning, simulating, and visualizing production lines.

1998 Acquisition of Anysim (Germany) - simulation software.

1999 Acquisition of Unicam (USA) - software applications for printed circuit boards assembly in the electronics industry. Tecnomatix's first major entry into the electronics industry.

1999 Acquisition of Prosolvia AB and Provolvio AB (Sweden) - simulation and flowchart technologies for production lines.

2000 Completed acquisition of FABMaster S.A (France), a leading provider of software solutions to the electronics industry.

2001 Strategic alliance signed with SAP (Germany), a leading ERP (Enterprise Resource Planning) product developer. SAP was previously a potential competitor. 
2002 Strategic R\&D and marketing alliance forged with EDS PLM Solutions, a leading product life cycle solution provider. EDS was previously a competitor. The fruits of this alliance, especially in the distribution network, are expected to materialize during 2003.

2002 Strategic alliance signed with Teradyne (USA) for the NPI subfield of the electronics market. Teradyne will focus on developing the CIMBridge product and Tecnomatix will incorporate it in its MPM solutions. This is a strengthening of a prior cooperating started in 1994.

2003 Strategic alliance signed with Fuji (Japan) to deliver added value to the companies' mutual clients. The client benefits are expected to materialize in the course of 2003.

2003 Acquisition of USDATA (USA), a leading developer of supervisory-level control (SCADA) and manufacturing execution systems (MES). The acquisition fulfills the Tecnomatix vision for a complete MPM solution spanning the entire manufacturing process lifecycle.

APPENDIX 3 - BALANCE SHEET AND P\&L

\section{Tecnomatix Technologies Ltd. \\ Consolidated Statements Of Operations U.S. \$ In Thousands, Except Per Share Data}

$\underline{\text { Revenues }}$

Software license fees

Services

$$
\text { Total revenues }
$$

Twelve Months Ended $\underline{12 / 31 / 2003} \quad \underline{12 / 31 / 2002}$

\begin{tabular}{rr}
$\$ 36,033$ & $\$ 36,385$ \\
50,224 & $\quad \underline{45,620}$ \\
\hline 86,257 & 82,005
\end{tabular}

10,114

15,281

136

2,180

14,960

42,491

4,673

General and administrative

Write-off of long-term investment

Impairment of software asset acq. from 3rd-party

In-process RD and acquisition related costs

Restructuring costs and assets impairment Total costs and expenses

$--$

937

3,530

$\underline{2,659}$

96,961

Operating income (loss)

Financial income (expense), net

$(10,704)$

Income (loss) before taxes on income

$(10,025)$

$\underline{(212)}$

Income (loss) after taxes on income

$(10,237)$

$\underline{(103)}$

Equity share in net income (loss) of affiliate Net income (loss)

$(10,340)$

Basic earnings (loss) per share: Diluted earnings (loss) per share:
$(0.94)$
Three Months Ended $\underline{12 / 31 / 2003} \quad \underline{12 / 31 / 2002}$

\begin{tabular}{rr}
$\$ 11,894$ & $\$ 9,898$ \\
13,306 & $\underline{11,510}$ \\
\hline 25,200 & 21,408
\end{tabular}

8,06

15,005

2,491

36,887

5,013

457

375

$--$

$\underline{651}$

83,753

$(1,748)$

(799)

(2,547)

$\underline{148}$

(2,399)

(431)

$(2,830)$

(0.27)

(0.27)
3,860

4,371

113

1,292

4,289

12,514

1,050

$\frac{11,510}{21,408}$

2,379

3,767

577

3,882

9,874

1,486

457

937

375

651

$\underline{1,172}$

29,606

23,448

$(4,406)$

$\underline{203}$

$(4,203)$

(171)

$(1,978)$

$\underline{122}$

(4,374)

(29)

$(4,403)$

$(1,856)$

(0.18)

(0.18) 
Weighted average number of shares outstanding:

$\begin{array}{llrrr}\text { Basic } & 11,054,556 & 10,607,140 & 11,914,113 & 10,695,830 \\ \text { Diluted } & 11,054,556 & 10,607,140 & 11,914,113 & 10,695,830\end{array}$

\section{Tecnomatix Technologies Ltd. Condensed Consolidated Balance Sheets U.S. \$ In Thousands}

$12 / 31 / 2003 \quad 12 / 31 / 2002$

Current Assets:

Cash and cash equivalents

$\begin{array}{rr}\$ 9,232 & \$ 10,466 \\ 70 & 5,981 \\ 29,190 & 27,671 \\ 5,747 & 5,284 \\ 44,239 & 49,402\end{array}$

Non-current Assets:

Non-current receivables

Long-term investments

Property and equipment, net

5,628

6,108

Goodwill, net

26,124

17,210

Acquired intangibles, net

2,443

13,046

$--$

Other assets, net

117,144

$\underline{16,613}$

Total assets

115,817

\section{APPENDIX 4 - SOFTWARE INDUSTRY FINANCIAL INDEXES}

The chart below shows the Tecnomatix stock (TCNO) traded on NASDAQ and compared to the NASDAQ market index (^IXIC) and the iShares Goldman Sachs Software Index (IGV). This Index includes companies that are producers of client/server, enterprise software, Internet software, PC, and entertainment software.

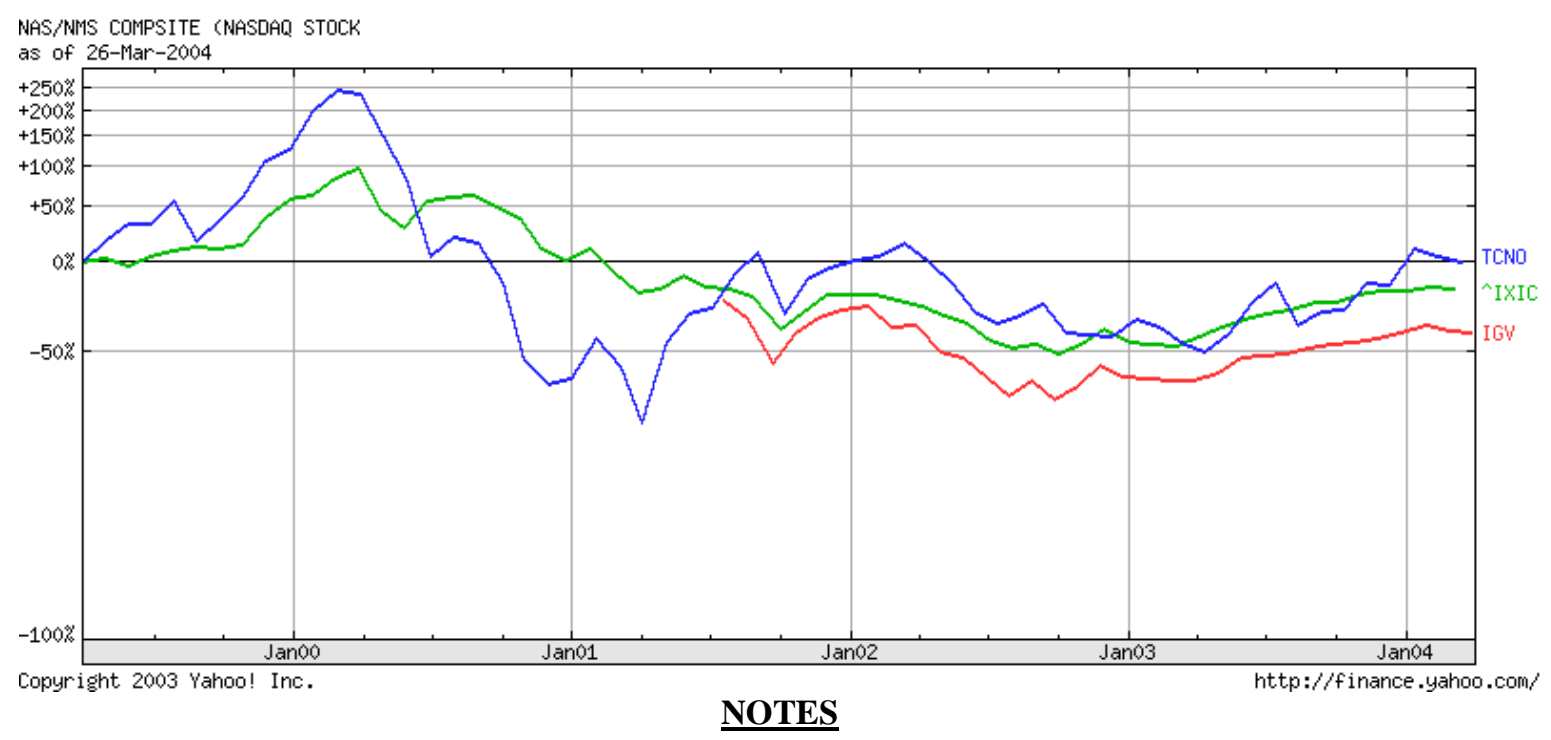

